\title{
Orbital tuning chronology for the Vostok climate record supported by trapped gas composition
}

\author{
Michael L. Bender* \\ Department of Geosciences, Princeton University, Princeton, NJ 08544 USA
}

Received 4 April 2002; accepted 19 July 2002

\begin{abstract}
We present data on the $\mathrm{O}_{2} / \mathrm{N}_{2}$ ratios of trapped gas samples for the entire length of the Vostok climate record. As in other cores, $\mathrm{O}_{2} / \mathrm{N}_{2}$ ratios in these samples are less than the atmospheric ratio, by a small and variable amount, because $\mathrm{O}_{2}$ is selectively excluded during the gas trapping process, and because $\mathrm{O}_{2}$ is also preferentially lost in poorly preserved core samples. Samples younger than $150 \mathrm{ka}$ have large and variable $\mathrm{O}_{2}$ depletions. Samples older than 200 ka have $\mathrm{O}_{2} / \mathrm{N}_{2}$ ratios that replicate well and vary smoothly with depth. We plot $\mathrm{O}_{2} / \mathrm{N}_{2}$ ratios of well replicated samples older than $160 \mathrm{ka}$, using a chronology derived by matching the $\delta^{18} \mathrm{O}$ of paleoatmospheric $\mathrm{O}_{2}\left(\delta^{18} \mathrm{O}_{\text {atm }}\right)$ to northern hemisphere June insolation. On this timescale, $\mathrm{O}_{2} / \mathrm{N}_{2}$ varies coherently with local $\left(78^{\circ} \mathrm{S}\right)$ summertime insolation. Based on time series analysis of the $\mathrm{O}_{2} / \mathrm{N}_{2}$ record and the dynamics of snow metamorphism at the surface, we conclude that summertime insolation influences physical properties of ice grains that control the degree of $\mathrm{O}_{2}$ exclusion during bubble closeoff. $\mathrm{O}_{2} / \mathrm{N}_{2}$ in Vostok is thus arguably a property that records local summertime insolation and can be used to test independent chronologies for the core. We show that the $\delta^{18} \mathrm{O}_{\mathrm{atm}}$ chronology, supported by the coincidence of $\mathrm{O}_{2} / \mathrm{N}_{2}$ ratios with insolation, is also compatible with recent radiometric dating of corals from high sea stands. We further successfully test the $\delta^{18} \mathrm{O}_{\text {atm }}$ tuning chronology by showing that it predicts a chronology for the GISP2 core which is essentially indistinguishable from the standard GISP2 chronology and, therefore, in excellent agreement with the radiometric chronology of Hulu Cave, China. An accurate chronology for the Vostok ice core is now in place.
\end{abstract}

(C) 2002 Elsevier Science B.V. All rights reserved.

Keywords: Pleistocene; paleoclimatology; ice cores; orbital tuning; geochronology

\section{Introduction}

It is about 40 years since Barnes et al. [1] and Rosholt et al. [2] published pioneering studies on radiometric methods of age determination for cli-

* Tel.: +1-609-258-2936; Fax: +1-609-258-5242.

E-mail address: bender@princeton.edu (M.L. Bender). mate-related sediments predating the useful age range of radiocarbon. However, accurate radiometric dating of important climate archives predating the period of ${ }^{14} \mathrm{C}$ accessibility has proven extremely difficult, important recent advances notwithstanding [3-6].

Limitations of radiometric methods have spawned attempts at dating by orbital tuning [7]. In this approach, one links a climate record to changes in insolation due to variations in the 
tilt of Earth's spin axis, precession of the equinoxes, and eccentricity of Earth's orbit about the sun. One then adjusts the chronology of the climate record to improve its match with changes in selected orbital properties. Orbital tuning rests on assumptions about how insolation variations influence environmental properties. It is therefore less desirable than radiometric dating, which defines ages with objective uncertainties. Nevertheless, orbital tuning has an important contribution to make, particularly as accurate radiometric ages increasingly allow one to test orbital chronologies at certain points in time. A property that depends directly on a specific insolation curve would be particularly valuable.

The Vostok ice core record is an important focus of dating studies because it contains long records of Antarctic and global climate properties [8]. $\delta D$ of Vostok ice reflects regional temperature. $\mathrm{CH}_{4}$ reflects changes in biogeochemical cycling on land, and its variations coincide with rapid climate changes in Greenland [9]. $\mathrm{CO}_{2}$ and $\mathrm{CH}_{4}$ concentrations of course denote changes in the atmospheric greenhouse forcing. The basic Vostok chronology comes from ice flow modeling [8]. Waelbroeck et al. [10] derived an orbital tuning chronology based on $\delta D$. Petit et al. [8] and Shackleton [11] derived orbital tuning chronologies based on the $\delta^{18} \mathrm{O}$ of paleoatmospheric $\mathrm{O}_{2}$ $\left(\delta^{18} \mathrm{O}_{\text {atm }}\right)$, and Parennin et al. [12] deduced an orbital tuning chronology based on multiple properties. $\delta^{18} \mathrm{O}_{\mathrm{atm}}$ has much of its variance at orbital frequencies [8,11], and its variations are highly coherent with tilt and precession [11]. Petit et al. [8] derived their chronology by linking mid-points of $\delta^{18} \mathrm{O}_{\mathrm{atm}}$ decreases to maxima in June insolation at $65^{\circ} \mathrm{N}$; they assumed constant phase derived from the known timescale of the last $20 \mathrm{ka}$ [1315]. Shackleton [11] used a much more elegant approach, filtering the $\delta^{18} \mathrm{O}_{\text {atm }}$ record at orbital frequencies and aligning the filtered curves with the time-dependent variations in tilt and precession. These two $\delta^{18} \mathrm{O}_{\text {atm }}$ timescales agree within 2 kyr.

We adopt the Petit et al. [8] $\delta^{18} \mathrm{O}_{\text {atm }}$ timescale (Table 1) as a hypothesis for the Vostok chronology, together with an additional control point at $3245 \mathrm{~m}$ depth (385.3 ka gas age) [12], and endeav-
Table 1

Depths, gas ages, and ice ages of control points

\begin{tabular}{lll}
\hline Depth & $\begin{array}{l}\text { Gas/orbital age } \\
(\mathrm{ka})\end{array}$ & $\begin{array}{l}\text { Ice age } \\
(\mathrm{ka})\end{array}$ \\
\hline 305 & 11 & 14 \\
900 & 58 & 62 \\
1213 & 84 & 88 \\
1528 & 105 & 109 \\
1863 & 128 & 130 \\
2110 & 151 & 156 \\
2350 & 176 & 181 \\
2530 & 199 & 202 \\
2683 & 220 & 225 \\
2788 & 244 & 247 \\
2863 & 265 & 269 \\
2972 & 293 & 297 \\
3042 & 314 & 317 \\
3119 & 335 & 337 \\
3245 & 385 & 388 \\
\hline
\end{tabular}

'Gas/orbital age' in the middle column refers to both the age of the insolation maximum and the orbital tuning gas age of the ice at that depth. 'Ice age' is the orbital tuning age plus the gas age-ice age difference.

or to test it with an improbable new climate proxy, the $\mathrm{O}_{2} / \mathrm{N}_{2}$ ratio of the trapped gases. Raynaud and Delmas [16] first measured this property. They showed that its value in their samples was about $1 \%$ less than in the atmosphere. Sowers [17], Craig et al. [18], and Sowers et al. [19] determined that $\mathrm{O}_{2}$ was depleted in samples from a wide range of ice cores. Craig et al. [18] proposed that $\mathrm{O}_{2}$ was depleted because its molecular diameter was smaller than that of $\mathrm{N}_{2}$. Channels of air at the bubble closeoff region at the base of the firn are at pressures above that of the ambient atmosphere due to compression by the overburden. Air is thus trying to escape from closing bubbles. When the necks of the closing channels reach molecular dimensions, there will be a point at which $\mathrm{O}_{2}$ molecules can escape while $\mathrm{N}_{2}$ is retained. The presence of excess $\mathrm{O}_{2}$ in air deep in the firn [20] confirms exclusion, but not necessarily its mechanism.

There are a number of implications to $\mathrm{O}_{2} / \mathrm{N}_{2}$ fractionation. First, fractionation apparently occurs by a similar mechanism when cores, brought to the surface, develop cracks, allowing some trapped air to escape. This process can lead to very large $\mathrm{O}_{2}$ depletions in poorly preserved sam- 
ples [21]. Second, the magnitude of $\mathrm{O}_{2}$ exclusion in well-preserved samples differs from site to site $[17,18]$. The variations must be linked to differences in physical properties of ice crystals and, hence, bubble closeoff processes. Third, $\mathrm{O}_{2}$ exclusion has so far obviated the possibility of determining changes in the $\mathrm{O}_{2} / \mathrm{N}_{2}$ ratio of air. Sowers et al. [19] and Smith [22] calculated that the postglacial accumulation of biomass, estimated assuming a global ocean $\delta^{13} \mathrm{C}$ increase of $0.3 \%$ o from glacial to interglacial times, would lead to a deglacial $\mathrm{O}_{2} / \mathrm{N}_{2}$ rise of about $1 \%$. Decreased interglacial nutrient drawdown, invoked to explain higher interglacial $\mathrm{CO}_{2}$ levels, would introduce an $\mathrm{O}_{2} / \mathrm{N}_{2}$ change of opposite sign and similar magnitude. Bubble closeoff fractionation is much larger, about $10 \%$, and dominates the signal.

In sites where there is annual layering, the closeoff processes are complicated by the fact that denser wintertime layers close first [23]. These closed layers then isolate the air remaining in intervening, permeable, summertime layers. At Vostok, where annual banding is absent, bubble closeoff occurs over a depth range of about 15 $\mathrm{m}$ [24], but the process is more uniform. Channels of air are open to the surface, and excluded $\mathrm{O}_{2}$ will leak back to the atmosphere rather than being trapped in layers and forced into late-closing bubbles [25]. In such cores, the $\mathrm{O}_{2} / \mathrm{N}_{2}$ ratio preserves a record of the physical properties of ice that govern the loss of $\mathrm{O}_{2}$ during closeoff. These ice properties must in turn depend on climate properties that govern the nature of snow at the surface of an ice sheet and its densification during burial. Hence $\mathrm{O}_{2} / \mathrm{N}_{2}$ has the potential to serve as a climate proxy. It has been largely neglected, however, in part because we lack a specific understanding of its climate dependence. As well, early results were noisy [17], and did not appear to reflect useful climate properties.

Smith [22] carried out a preliminary analysis of the $\mathrm{O}_{2} / \mathrm{N}_{2}$ record in the deeper part of the Vostok ice core. She demonstrated two features which underlie much of the following interpretation: $\mathrm{O}_{2} / \mathrm{N}_{2}$ does not follow the isotopic temperature curve, and $\mathrm{O}_{2} / \mathrm{N}_{2}$ has a strong similarity to insolation at Vostok. We show that $\mathrm{O}_{2} / \mathrm{N}_{2}$ is a proxy for local insolation, and use it to validate the $\delta^{18} \mathrm{O}_{\text {atm }}$ orbital tuning timescale. We then extend Shackleton's [11] tests of the $\delta^{18} \mathrm{O}_{\text {atm }}$ chronology and show that it is consistent with recent results of radiometric dating.

\section{Experimental methods and results}

Samples were analyzed using the method described by Sowers [17] and Sowers et al. [19], with one modification. Briefly, ice is melted in a vacuum container and refrozen from the bottom. The headspace gas is frozen into a stainless steel tube at liquid helium temperature. Samples from the Vostok 3G core were remelted, refrozen, and the headspace gases again transferred to the stainless steel tube. Samples from the Vostok $4 \mathrm{G}$ and $5 \mathrm{G}$ cores were melted only once. Single melting does not affect the measured isotopic composition, but it causes $\mathrm{O}_{2} / \mathrm{N}_{2}$ ratios to be artifactually low by about $3 \%$ due to selective trapping of the more soluble $\mathrm{O}_{2}$ in refrozen ice (unpublished results). Reproducibility is excellent in single melt samples, as indicated by the fact that $\mathrm{O}_{2} / \mathrm{N}_{2}$ ratios of most $5 \mathrm{G}$ samples agree to better than $\pm 0.5 \%$.

The trapped gas sample collected in the stainless tube is warmed, equilibrated, admitted to a mass spectrometer, and analyzed against a dry air standard. $\delta^{18} \mathrm{O}$ of $\mathrm{O}_{2}$ and $\delta^{15} \mathrm{~N}$ of $\mathrm{N}_{2}$ are measured by double collector mass spectrometry using a Finnigan 251 or 252 mass spectrometer. $\mathrm{O}_{2} / \mathrm{N}_{2}$ was measured by single collector mass spectrometry (peak jumping) in all samples, from the ratio of ${ }^{16} \mathrm{O}_{2}$ to ${ }^{14} \mathrm{~N}_{2}$. It was measured by double collection in a subset of samples, from the ratio of ${ }^{16} \mathrm{O}_{2}$ to ${ }^{15} \mathrm{~N}^{14} \mathrm{~N}$. Agreement between the two methods was very good after correcting for the $\delta^{15} \mathrm{~N}$ of trapped $\mathrm{N}_{2}$. The reference gas was calibrated against clean dry air. Corrections for various interferences are described in Sowers [17] and Sowers et al. [19]. $\mathrm{O}_{2} / \mathrm{N}_{2}$ ratios presented here are all corrected for gravitational fractionation [18]. Results are presented in Fig. 1. All data are available online at the National Snow and Ice Data Center (http://nsidc.org/data/agdc.html). The data from the singly melted samples from the $4 \mathrm{G}$ and $5 \mathrm{G}$ cores are not corrected for incomplete collec- 
tion of $\mathrm{O}_{2}$ during sampling. We interpret the downcore variability in the $\mathrm{O}_{2} / \mathrm{N}_{2}$ ratio of these samples, but do not draw any conclusions based on the absolute value of the ratio. Only samples from the $4 \mathrm{G}$ and $5 \mathrm{G}$ cores came from the deeper section in which $\mathrm{O}_{2} / \mathrm{N}_{2}$ varied systematically with age.

\section{Controls on the $\mathrm{O}_{2} / \mathrm{N}_{2}$ ratios of ice core samples}

\subsection{Character of the $\mathrm{O}_{2} / \mathrm{N}_{2}-$ depth relationship at Vostok}

$\mathrm{O}_{2} / \mathrm{N}_{2}$ ratios for all samples of the Vostok $3 \mathrm{G}$, $4 \mathrm{G}$ and $5 \mathrm{G}$ ice cores are plotted in Fig. 1 vs. ice age. Normally, gas composition in glacial ice is plotted vs. gas age. Gas age is less than ice age because air is not fully captured until it is sealed in enclosed bubbles at the base of the firn. At
Vostok, sealing occurs about $100 \mathrm{~m}$ below the surface. The current depth and ice age at this closeoff depth are $\sim 100 \mathrm{~m}$ and $3.3 \mathrm{kyr}$. The gas age-ice age difference was $\sim 7 \mathrm{kyr}$ during glacial maxima. We plot data vs. ice age rather than gas age because we regard $\mathrm{O}_{2} / \mathrm{N}_{2}$ as a proxy for physical properties of ice set at the surface, rather than as a measure of the air ratio. The age term of merit therefore is the time of snow deposition (and metamorphism) at the surface, rather than the time of sealing.

Nearly all samples are depleted in $\mathrm{O}_{2}$. As discussed above, this depletion results from two processes. The first is selective exclusion of $\mathrm{O}_{2}$ during the gas trapping process [18], which we call closeoff fractionation. The second is selective loss of $\mathrm{O}_{2}$ in poorly preserved samples of cored ice [21]. We associate such loss with cracks or microcracks, and term this mode core cracking fractionation.

Many samples with ages of $\sim 40-80 \mathrm{ka}$ are ex-

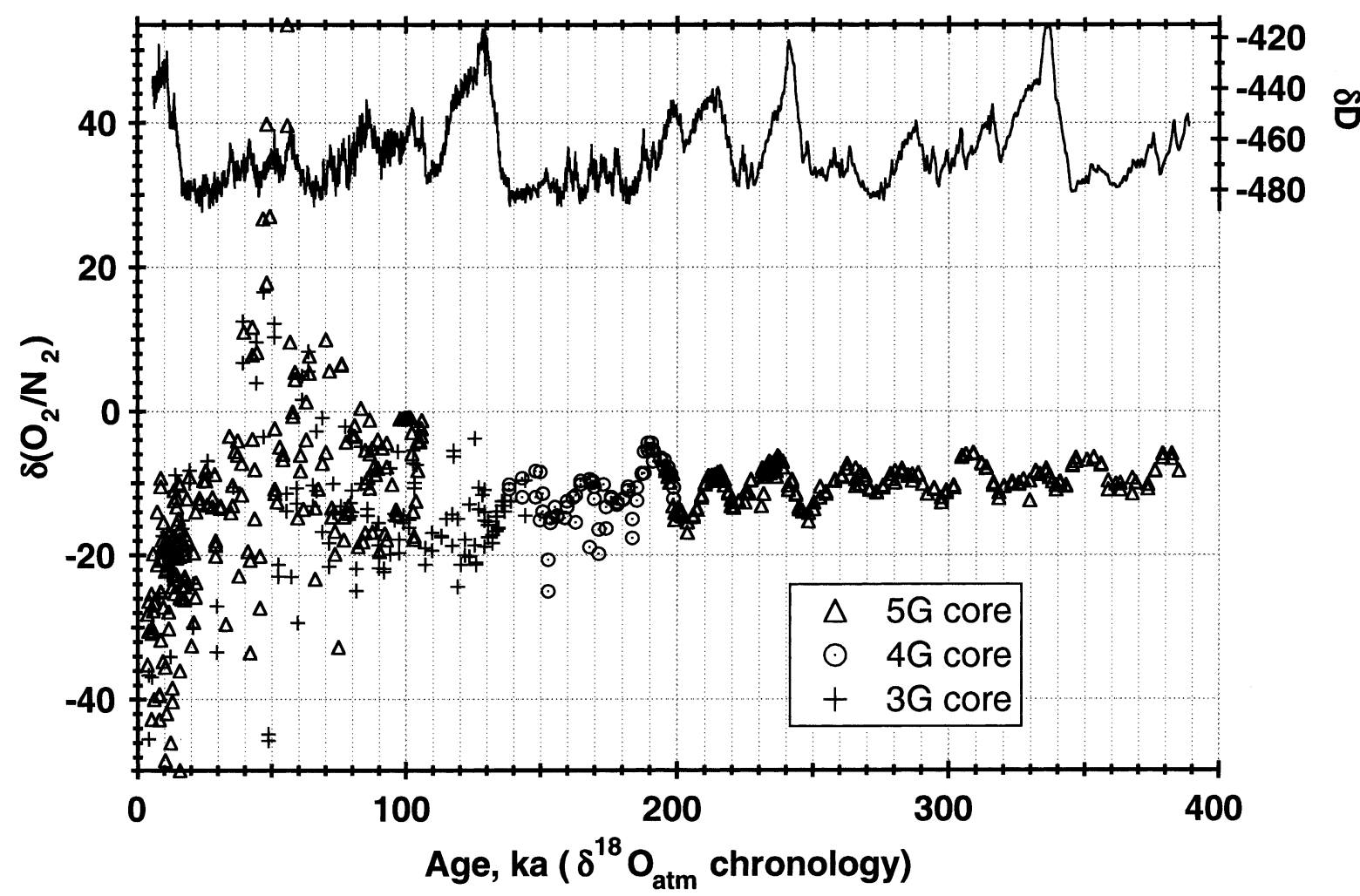

Fig. 1. $\mathrm{O}_{2} / \mathrm{N}_{2}$ vs. age and $\delta D$ vs. age in the Vostok ice core. $\mathrm{O}_{2} / \mathrm{N}_{2}$ ratios for $4 \mathrm{G}$ and $5 \mathrm{G}$ samples are systematically low, by $\sim 3 \%$, due to incomplete degassing during single melt extractions (see text). 
ceptional in that they are enriched in $\mathrm{O}_{2}$ rather than depleted [21]. This enrichment occurs in the depth interval at which $\mathrm{O}_{2}$ and $\mathrm{N}_{2}$ dissolve in the ice as gas hydrates [26,27]. $\mathrm{O}_{2}$ dissolves first, and gases dissolved in the ice are much less prone to post-coring loss than gases remaining in bubbles. Therefore $\mathrm{N}_{2}$, which is enriched in bubbles $[26,27]$, is preferentially lost in this transition zone, and residual trapped gases are enriched in $\mathrm{O}_{2}$.

Selective loss of $\mathrm{O}_{2}$ in shallow ice results from the presence of gases as bubbles under high hydrostatic pressure. Gases expand and induce fracturing when ice samples are brought to the surface. In the deeper part of the core, gases exist completely dissolved in the ice. Here, the quality of sampled ice is excellent, and the original gas composition is retained. Three observations are consistent with the idea that $\mathrm{O}_{2}$ is selectively lost by core cracking fractionation in the upper part of the core, while the primary signal of bubble closeoff fractionation is retained in almost all of the deeper samples. First, scatter in $\mathrm{O}_{2} / \mathrm{N}_{2}$ ratios, expressed either as deviation from the mean of replicates or as variability of nearby samples, decreases with depth. Second, the upper bound of $\mathrm{O}_{2} / \mathrm{N}_{2}$ ratios is similar throughout much of the core, while the lower bound is much less negative (reflecting less core cracking loss) below $200 \mathrm{ka}$ than prior to $50 \mathrm{ka}$. Third, $\mathrm{O}_{2} / \mathrm{N}_{2}$ ratios for samples younger than $100 \mathrm{ka}$ do not vary smoothly with depth, while ratios do vary smoothly prior to $\sim 190 \mathrm{ka}$.

All data for samples older than $150 \mathrm{ka}$ are plotted vs. age in Fig. 2. The mean is plotted where replicates agree to $\pm 0.5 \%$. Individual data points are plotted for replicates that did not agree to this level, and for depths where only one sample was analyzed. Many of these unreplicated or poorly replicated points fall very close to the well replicated curve. Most others have lower $\mathrm{O}_{2} / \mathrm{N}_{2}$ ratios, a difference that we attribute to poor core quality. A small number have higher $\mathrm{O}_{2} / \mathrm{N}_{2}$ ratios. At $\sim 190 \mathrm{ka}$, these high $\mathrm{O}_{2} / \mathrm{N}_{2}$ values may

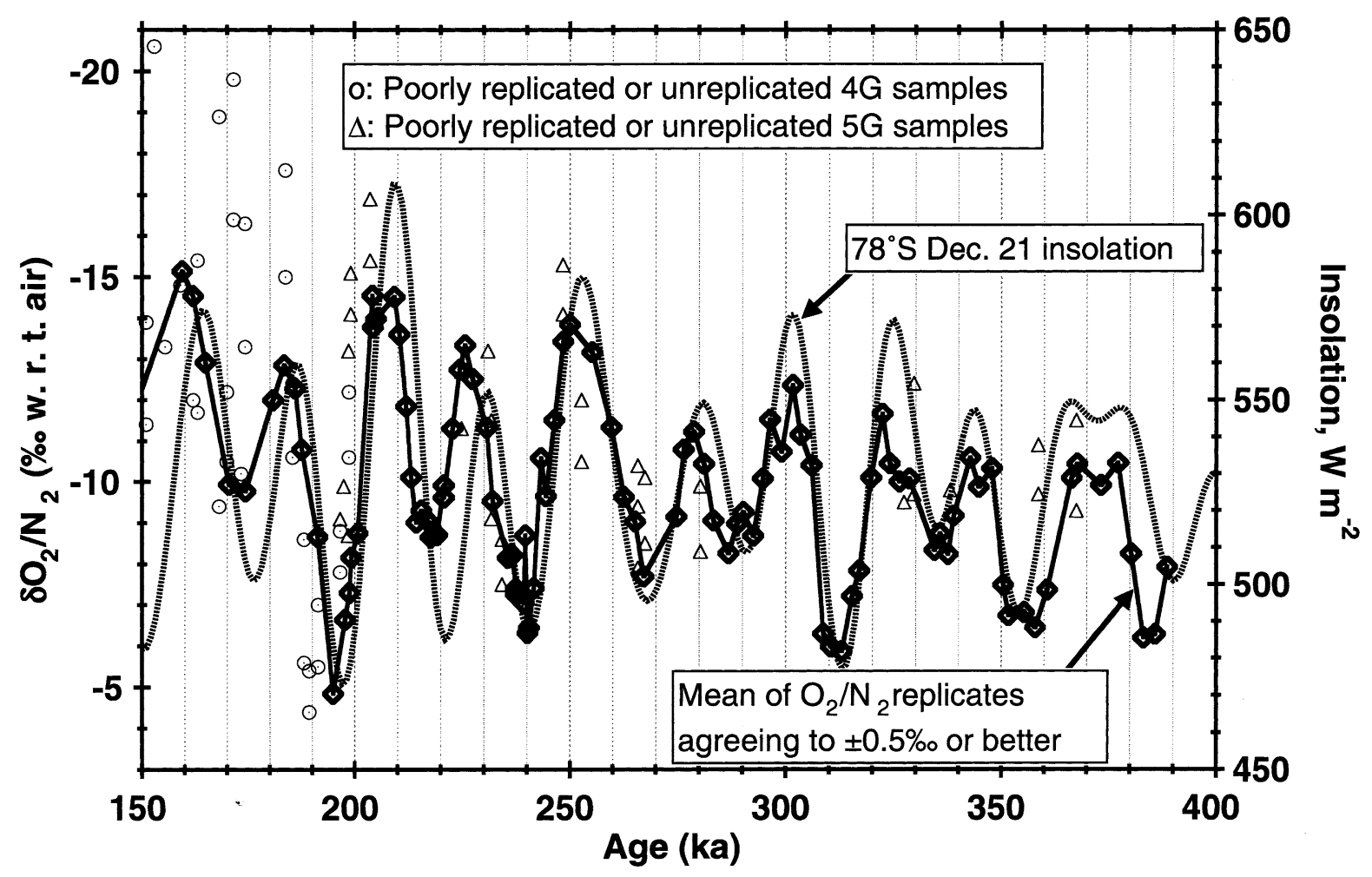

Fig. 2. $\mathrm{O}_{2} / \mathrm{N}_{2}$ and insolation vs. age for the period from $150-400 \mathrm{ka}$. 
be closer to original ratios than a (fortuitously?) well replicated nearby depth with lower ratios. The amplitude of the systematic $\mathrm{O}_{2} / \mathrm{N}_{2}$ variations prior to $\sim 190 \mathrm{ka}$, of order $10 \%$, is too large to attribute to atmospheric variability (Sowers et al. [19]). It must be due primarily to variable exclusion of $\mathrm{O}_{2}$ during bubble closeoff.

\subsection{Relationship between $\mathrm{O}_{2} / \mathrm{N}_{2}$ and insolation}

We overlay the curve of $78^{\circ} \mathrm{S}$ summertime (actually December 21) insolation vs. time on the clean plot of $\mathrm{O}_{2} / \mathrm{N}_{2}$ vs. age (Fig. 2). We also plot $\delta^{18} \mathrm{O}_{\text {atm }}$ and June insolation at $65^{\circ} \mathrm{N}$ (Fig. 3). Petit et al. [8] derived the orbital chronology discussed above by tuning $\delta^{18} \mathrm{O}_{\mathrm{atm}}$ to the latter target.

A strong similarity is evident between curves of $\mathrm{O}_{2} / \mathrm{N}_{2}$ (actually $-\mathrm{O}_{2} / \mathrm{N}_{2}$ ) vs. age, and December
21 insolation vs. age. The curves have the same number of cycles during the relevant time between 160-390 ka. They have extrema at similar ages. They appear coherent in that cycles with larger insolation excursions correspond to cycles with larger $\mathrm{O}_{2} / \mathrm{N}_{2}$ variations. The correlation coefficient $\left(\mathrm{R}^{2}\right)$ for the two curves, interpolated at $1 \mathrm{kyr}$ intervals, is 0.61 . It would be considerably higher if one shifted the chronology by a few thousand years to eliminate the small phase differences observed for some cycles.

Why does $\mathrm{O}_{2} / \mathrm{N}_{2}$ covary with insolation? Variability in this property is governed by some incompletely understood physical property(s) of the ice. The nature of control is likely to be much simpler at a very low accumulation rate site like Vostok than at a higher accumulation rate site with annual density layering and a complex bubble closeoff history in the lock-in

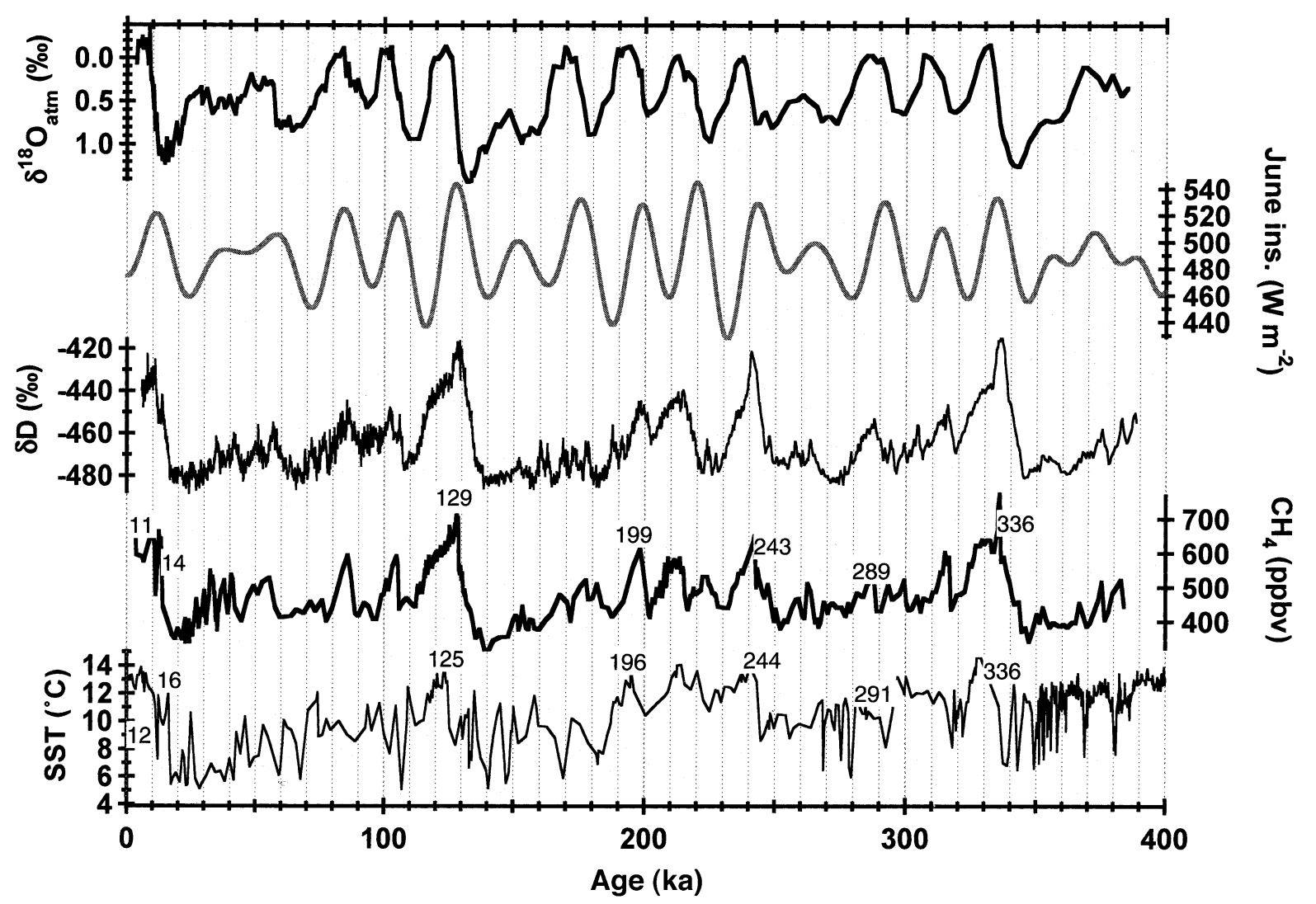

Fig. 3. Comparison of long term climate records from Vostok and ODP Site 980. 
zone [23]. In fact, Smith [22] compared $\mathrm{O}_{2} / \mathrm{N}_{2}$ variations in the GISP2 and Vostok cores, and reached exactly this conclusion. Variations in GISP2 clearly reflect climate change in some intervals, but the relation between $\mathrm{O}_{2} / \mathrm{N}_{2}$ and climate properties is less stable over a long time interval.

We can dismiss annual average temperature (based on $\delta D$ ) and accumulation rate (which varies inversely with temperature) as properties controlling $\mathrm{O}_{2} / \mathrm{N}_{2}$ variations, to which they bear little resemblance (Fig. 1). A number of other meteorological properties affect physical properties of snow and could therefore influence $\mathrm{O}_{2} /$ $\mathrm{N}_{2}$. Winds produce high-density surface snow crusts [28,29]. They also induce convection in the snowpack, leading to water vapor transport and the formation of faceted crystals [30]. Wintertime cloudiness causes surface warming, thereby affecting snow metamorphism. Summertime insolation itself leads to evaporation and grain growth, as discussed below, and is clearly a critical property influencing the metamorphism of snow near the surface of ice sheets. Summertime properties are likely to be particularly important because snow metamorphism is more rapid when temperatures are warm and water vapor concentration is high.

Results of spectral analyses, shown in Fig. 4, give some insight into environmental properties influencing bubble closeoff fractionation. These analyses were done using detrended records between 160-385 ka interpolated at 2 kyr intervals, which approximately correspond to the resolution of the data, and with 80 lags. The spectral relationship between the Vostok $\mathrm{O}_{2} / \mathrm{N}_{2}$ curve and $\delta^{18} \mathrm{O}_{\text {atm }}$ (upper left) is similar, in two fundamental ways, to the relationship between $78^{\circ} \mathrm{S}$ summer isolation and June insolation at $65^{\circ} \mathrm{N}$ (lower left). Both pairs of curves have strong spectral peaks and coherent amplitude variations at the periods of tilt (41 ka) and precession (19-23 ka). As well, phasing for both pairs of curves differs by $\sim 180^{\circ}$ between tilt and precession. Importantly, these similarities persist regardless of the exact Vostok chronology, because the $\delta^{18} \mathrm{O}_{\text {atm }}$ and $\mathrm{O}_{2} / \mathrm{N}_{2}$ records are in the same core. The results strongly support the idea that both $\delta^{18} \mathrm{O}_{a t m}$ and
$\mathrm{O}_{2} / \mathrm{N}_{2}$ vary coherently with some appropriate insolation curves.

The $\sim 180^{\circ}$ phase shift between tilt and precession periods shows that $\mathrm{O}_{2} / \mathrm{N}_{2}$ must depend on insolation in the opposite hemisphere from that influencing $\delta^{18} \mathrm{O}_{\mathrm{atm}}$. The argument is that tilt forcing is in phase between hemispheres (high tilt leads to warm summers everywhere), while precession forcing is out of phase. We follow previous workers (e.g., [31]) in assuming that orbital variations of $\delta^{18} \mathrm{O}_{\mathrm{atm}}$ are set by northern hemisphere summer insolation. The arguments for this assumption are that northern summer insolation influences three properties that cause variations in $\delta^{18} \mathrm{O}_{\mathrm{atm}}$ : volume of continental ice sheets, the fertility of the land biosphere (more of which is in the north), and hydrologic fractionation of isotopes and hence the $\delta^{18} \mathrm{O}$ of leaf water [32]. If $\delta^{18} \mathrm{O}_{\mathrm{atm}}$ varies with northern hemisphere insolation, $\mathrm{O}_{2} / \mathrm{N}_{2}$ must respond to southern hemisphere insolation.

We next discuss results of cross-spectral analysis for curves of $\mathrm{O}_{2} / \mathrm{N}_{2}$ vs. age and $78^{\circ} \mathrm{S}$ summertime insolation vs. age (Fig. 4, lower right). High coherency and stable phases confirm one's visual impression that $\mathrm{O}_{2} / \mathrm{N}_{2}$ variations strongly resemble the insolation curve. Furthermore, $\mathrm{O}_{2} / \mathrm{N}_{2}$ variations are nearly in phase with insolation, given our adopted chronology. The property $-\mathrm{O}_{2} / \mathrm{N}_{2}$ lags insolation by $30^{\circ}(\sim 2 \mathrm{kyr})$ at the period of precession, and leads by $15^{\circ}(\sim 2 \mathrm{kyr})$ at the period of tilt.

These spectral properties show that $\mathrm{O}_{2} / \mathrm{N}_{2}$ may respond to local summertime insolation, but we need to consider other possibilities as well. We reject control by spring or fall insolation at lower latitudes, because the spring and fall insolation curves are less coherent with the $\mathrm{O}_{2} / \mathrm{N}_{2}$ curve. We also reject control by wintertime insolation. Winter insolation falls towards zero south of the Antarctic circle, and thus cannot induce variations in snow properties. One could argue that winter insolation at mid and low latitudes of the southern hemisphere influences $\mathrm{O}_{2} / \mathrm{N}_{2}$ by causing variations in windspeed or cloudiness on the Antarctic plateau. Both properties could influence snow metamorphism: winter clouds lead to warmer temperatures (e.g., [33]), while winds in- 

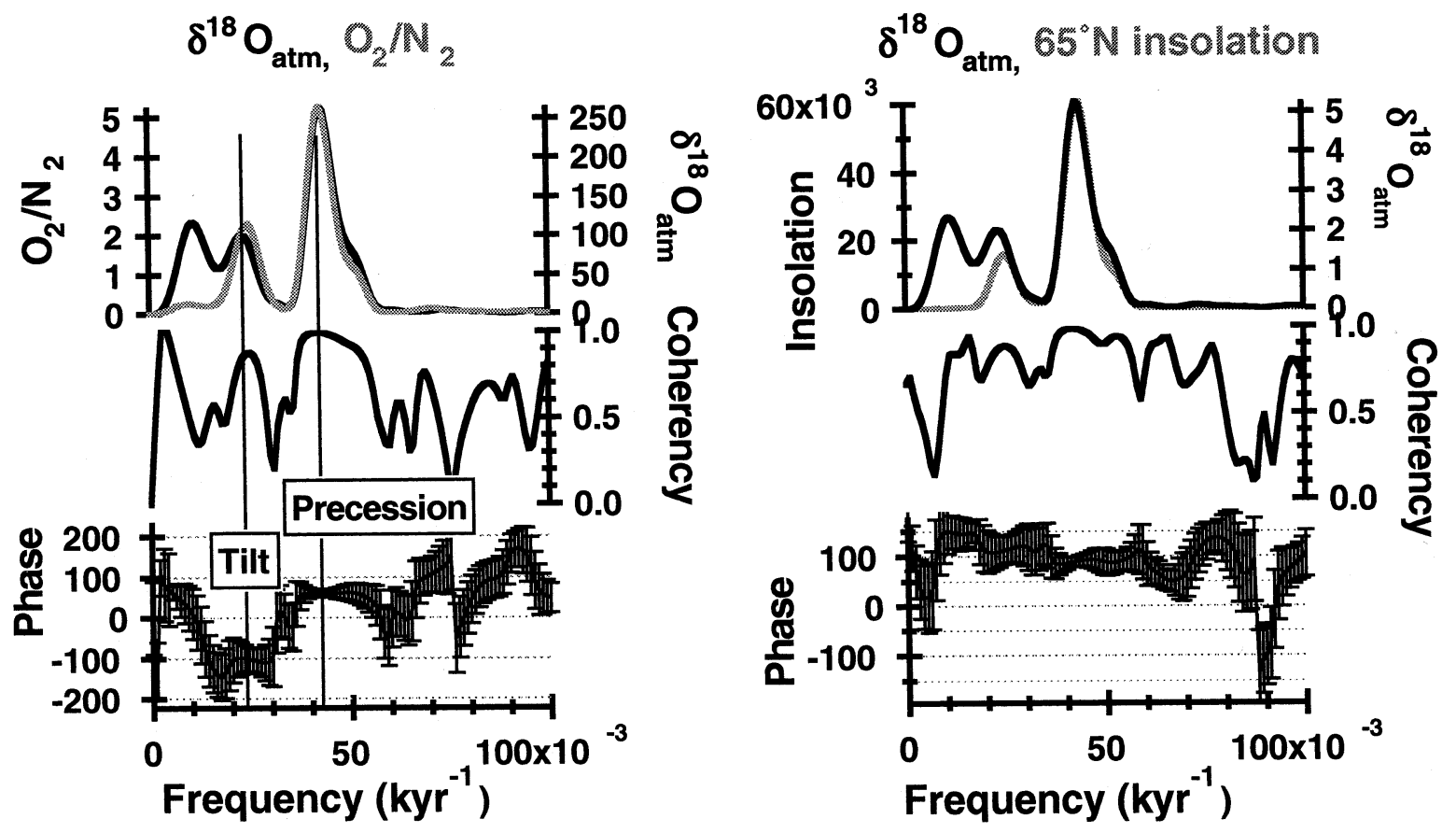

$65^{\circ} \mathrm{N}$ insolation, $78^{\circ} \mathrm{S}$ insolation

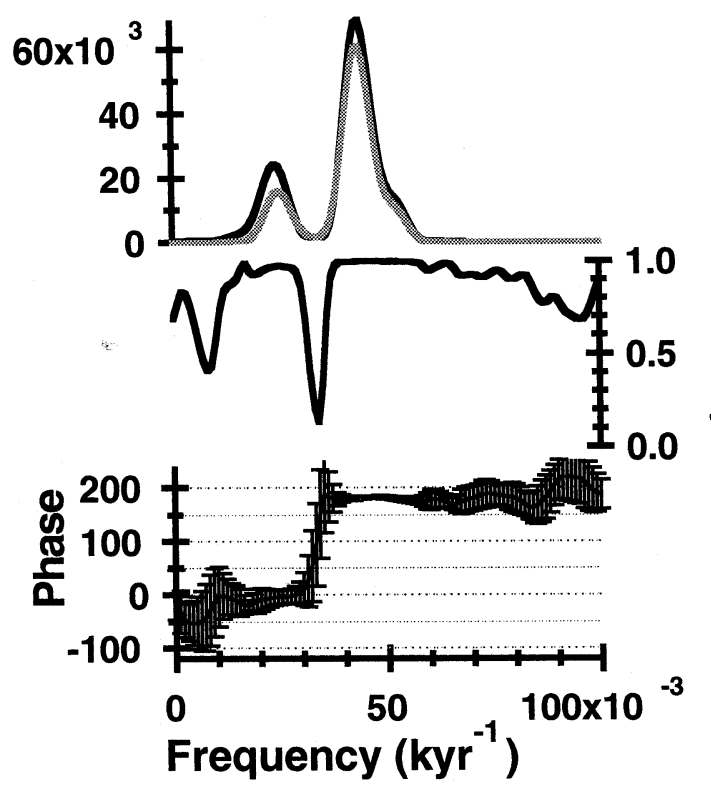

$78^{\circ} \mathrm{S}$ insolation, $-\mathrm{O}_{2} / \mathrm{N}_{2}$

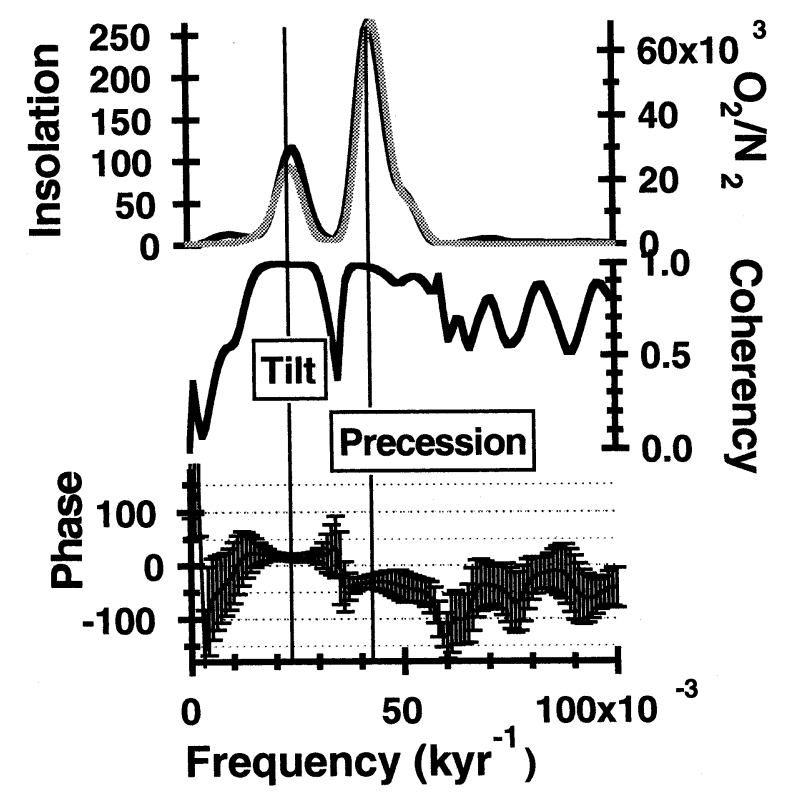


crease the density of surface snow [34]. Control by winter insolation requires that climate signals are transmitted from the low or mid latitudes to the Antarctic Plateau, with almost no loss of fidelity to the original winter insolation curve. We regard this scenario as extremely unlikely, because no southern hemisphere climate property varies as coherently with insolation as does $\mathrm{O}_{2} / \mathrm{N}_{2}$. Furthermore, most processes metamorphosing snow at the surface involve vapor phase transport (e.g., [33]). This mode of transport is unlikely to be important during the cold Antarctic winter.

\subsection{Variable insolation and the surface metamorphism of snow}

We argue here that solar insolation itself directly influences ice properties that lead to $\mathrm{O}_{2} /$ $\mathrm{N}_{2}$ variations. Solar insolation is mostly absorbed in the upper $\sim 2 \mathrm{~cm}$ of the polar ice sheet $[34,35]$. This absorption induces considerable surface warming, reflected, for example, in diurnal temperature variations of up to $20^{\circ} \mathrm{C}$ in the surface of the ice sheet at Summit, Greenland [36]. These variations lead to evaporation and the formation of surface hoars (low density, large grain-size layers formed by evaporation), which are transformed by burial into depth hoars (e.g., [29]). Surface heating and thermal conduction also lead to the well-known annual cycle of temperature variations in the firn, again with amplitudes of 10's of degrees C (e.g., [34]). In autumn, as surface ice cools, there is a sharp increase of temperature with depth. This increase induces sublimation (depth hoar formation), upward migration of water vapor, and its subsequent deposition in colder, shallower snow (e.g., [29]). Depth hoar layers are common features of snow on the Antarctic Plateau [28,37].

December 21 solar insolation at $78^{\circ} \mathrm{S}$ varies by up to $31 \%$ (expressed as a fraction of the minimum value) between 160-385 ka (Fig. 2). Variations in summertime insolation would lead to significant changes in the magnitude of surface ice sheet warming during summer that causes surface hoar formation. They would also cause changes in the amplitude of subsurface temperature gradients in autumn that cause in situ formation of depth hoars. Several factors might work to amplify this increase in surface and depth hoar formation at times of higher summertime insolation. First, albedo decreases with lower zenith angles (e.g., [3840]), so that a greater fraction of incident insolation is absorbed at times of high obliquity. Second, increased insolation would lead to more rapid snow metamorphism, larger grain size, and decreased density $[33,36,38,40]$. Larger grain size translates to lower albedo $[33,38,40]$ and further warming. Third, increased insolation and warmer surface temperatures lead to smaller summertime temperature inversions and weaker winds [41]. According to Grenfell et al. [38], winds resuspend snow grains and allow their size to be reduced by sublimation. The smallest grains then settle to the surface last, leading to small surface grain size and high albedo. Summers of high insolation would have low winds, less resuspension of surface snow, larger grain size, and lower albedo. Fourth, hoar formation reduces density and hence thermal conductivity [33]. This change would lead to larger temperature gradients in the subsurface firn, further enhancing both surface and depth hoar formation.

\subsection{Grain properties and bubble closeoff fractionation}

We propose that the signature(s) of near-surface snow metamorphism persist, despite attenuation, throughout the firn, and remains to influ-

Fig. 4. Results of spectral and cross spectral analyses. In each quadrant, the top plot shows spectral power, the middle plot shows coherency, and the lower plot shows the phase and its uncertainty. Upper left: $\delta^{18} \mathrm{O}_{\text {atm }}$ and $\mathrm{O}_{2} / \mathrm{N}_{2}$; in the top plot, black corresponds to $\delta^{18} \mathrm{O}_{\text {atm }}$ and gray corresponds to $\mathrm{O}_{2} / \mathrm{N}_{2}$. Lower left: $65^{\circ} \mathrm{N}$ June 21 insolation and $78^{\circ} \mathrm{S}$ December 21 insolation; in the top plot, black corresponds to the $65^{\circ} \mathrm{N}$ curve, and gray corresponds to the $78^{\circ} \mathrm{S}$ curve. Upper right: $\delta^{18} \mathrm{O}_{\text {atm }}$ and $65^{\circ} \mathrm{N}$ June 21 insolation; in the top plot, black corresponds to the $\delta^{18} \mathrm{O}_{\text {atm }}$ curve, and gray corresponds to $65^{\circ} \mathrm{N}$ insolation. Lower right: $\mathrm{O}_{2} / \mathrm{N}_{2}$ and $78^{\circ} \mathrm{S}$ December 21 insolation; in the top plot, black corresponds to the $78^{\circ} \mathrm{S}$ curve and gray corresponds to $-\mathrm{O}_{2} / \mathrm{N}_{2}$. 
ence the nature of bubble closeoff and the extent of $\mathrm{O}_{2}$ exclusion. One can envision four grain properties that might influence the magnitude of $\mathrm{O}_{2}$ exclusion: grain size, the distribution of grain size about the mean, grain shape and $c$-axis anisotropy. First consider shape. Alley [42] has shown that grains in snow from cores taken in West Antarctic ice streams resemble prolate spheroids, with long axes preferentially pointing upward. He did not report the variation in nonsphericity with depth. However, other measures of anisotropy decreased with depth, including preferential vertical orientation (Alley's figure 2) and anisotropy of the ice-air interface (Alley's figure 4). Jun et al. [43], on the other hand, show that sphericity of grains at Law Dome appears to increase towards 1.00 (perfect sphere) from 0 to $\sim 10 \mathrm{~m}$ depth. But sphericity actually decreases at greater depth, presumably due to bonding or necking between crystals. Such changes could plausibly influence $\mathrm{O}_{2} / \mathrm{N}_{2}$ fractionation when bubbles close.

Second, consider $c$-axis anisotropy. Few data are available about this property in firn. Nakawo [44] studied $c$-axis anisotropy in a firn core from Mizuho Station, Antarctica. He found that $c$-axes were preferentially oriented in the vertical at shallow depths. Deeper, anisotropy decreased, and was nearly absent at the closeoff depth. Jun and Jacka [45] showed that $c$-axes tend to be oriented towards the vertical in firn from the DE 08 ice core, Law Dome, Antarctica. They imply that this effect is due to flow, which is well known to induce $c$-axis anisotropy in deeper ice [46]. The extent of $c$-axis anisotropy in firn is unknown at slowly accumulating sites like Vostok.

Third, consider grain size. There are two regimes of grain growth. Grain growth is particularly rapid in the upper $\sim 2 \mathrm{~m}$ of the firn (e.g., [47], and citations below). This rapid growth is attributed to vapor transport near the surface, induced by convection and temperature variability according to processes described above. (Interestingly, the rapid growth zone is absent at Law Dome site DE 08 [43]. Presumably, extraordinarily rapid accumulation here overwhelms the metamorphic capacities of the snow.) Large daily and seasonal temperature gradients would also pro- mote rapid grain growth because the average of rate constants in an environment of variable temperature will be greater than the rate constant at the average temperature. This effect undoubtedly contributes, but its magnitude is not that large.

Below a 2-m depth, grain size increases at a rate that depends simply on mean annual temperature. The theory of grain growth in firn is fairly well understood. The driving force for grain growth is the decrease in free energy associated with larger grain sizes (e.g., [29]). Accordingly, grains less than a critical radius lose mass while larger grains accumulate mass. Theory predicts that the square of the mean grain radius increases linearly with age $[29,47]$. Ample observations confirm this prediction for firn at Vostok and elsewhere [43,4550]. The rate term for firn in remote polar areas is apparently unaffected by impurities, and is fixed by temperature alone (e.g., [49]).

Several papers report data on grain size vs. depth $[47,49,50]$. These studies give compelling evidence for the importance of snow metamorphism on Vostok ice properties both at shallow depths and at the bubble closeoff horizon. Plots of mean grain $r^{2}$ ( $r=$ radius) vs. age extrapolate to crystal sizes of about $0.3-2 \mathrm{~mm}^{2}$ at the surface $($ depth $=0)$. However, surface grain sizes are far smaller. According to Grenfell et al. [38], grain radii are $0.03-0.1 \mathrm{~mm}$ in a thin surface layer (actually two layers as they model it). These radii correspond to mean grain $r^{2}$ of $9 \times 10^{-4}$ to $10^{-2}$ $\mathrm{mm}^{2}$. By a depth of $2-5 \mathrm{~m}$, grain radii ${ }^{2}$ have increased to a value that lies on the straight line characterizing mean $r^{2}$ vs. age to the base of the firn and below. At the base of the firn, mean $r^{2}$ lies in the range of $0.5-4 \mathrm{~mm}^{2}[47,49]$. Thus the increase in $r^{2}$ in the top $\sim 2 \mathrm{~m}$ is comparable to its increase in the remainder of the firn. Furthermore, the importance of the surface increase is greater at cold sites than at warm sites. Comparing results from a single paper shows that the surface layer increase in $r^{2}$ (estimated from the zero-depth intercept of $r^{2}$ vs. age in the underlying firn) is greater at cold sites [47,49]. This result reflects slower accumulation at colder sites. Snow at cold sites spends more time in the shallow zone of diurnal and seasonal temperature var- 
iations. This increased time promotes snow metamorphism more than colder temperatures retard metamorphism. At Vostok, fully half the grain growth (expressed as radius ${ }^{2}$ ) occurs in the upper $\sim 2 \mathrm{~m}$ [49]. Expressed in $\log$ terms, $r^{2}$ increases by three units (from $\sim 10^{-3} \mathrm{~mm}^{2}$ to $1 \mathrm{~mm}^{2}$ ) in the upper $\sim 2 \mathrm{~m}$, but only 0.3 units (from 1 to $2 \mathrm{~mm}^{2}$ ) from $\sim 2-\mathrm{m}$ depth to the base of the firn. Thus it is clear that snow metamorphism plays a large role in determining the value of grain size, if not other properties, at the closeoff depth.

Finally, consider the fourth property, the variance of grain size about the mean. Alley [42] regarded the variance as being constant when normalized to the mean radius. Arnaud [49] found systematic depth variations in grain size distributions at Vostok, but these changes were small. Factors controlling the initial variance in grain size remain to be studied. Nevertheless, grain size variance, like grain size itself, is shown to be another property set at the surface and transmitted to depth.

We can make only the most general statement about the mechanism by which grain size or its variance might control fractionation of $\mathrm{O}_{2}$ and $\mathrm{N}_{2}$ at the base of the firn. An important observation is that gases are fractionated during bubble close off and core cracking, while isotopes are nearly unfractionated. For example, the $\delta^{18} \mathrm{O}$ of $\mathrm{O}_{2}$ in poorly preserved samples of trapped gas in Vostok is never elevated by more than about $0.1 \%$, even when $\mathrm{O}_{2} / \mathrm{N}_{2}$ is as low as $-50 \%$ (e.g., compare Vostok and GISP2 $\delta^{18} \mathrm{O}_{\text {atm }}$ records in [51]). Thus the fractionation is not mass-dependent. Rather, it depends on some molecular property, presumably diameter [18]. One reasonable speculation is that atomic distances at some crystal boundaries are comparable to the molecular diameter of $\mathrm{O}_{2}$, but smaller than that of $\mathrm{N}_{2}$. Such a situation might arise at boundaries of randomly oriented crystals. $\mathrm{O}_{2}$ could then escape along these boundaries. Eventually, boundaries of adjacent grains would lengthen, the escape path would become long, and loss would cease.

In conclusion, one can envision a chain of processes by which summertime insolation influences surface grain properties, deep grain properties, and $\mathrm{O}_{2} / \mathrm{N}_{2}$ fractionation during bubble closeoff.
However, it remains for us to identify the exact grain property(s) that affect closeoff fractionation. We also do not know the precise way in which the closeoff process fractionates gases according to their molecular diameters.

\section{Comparing Vostok orbital tuning chronologies with radiometric dates}

We are now in a position to derive a new orbital tuning chronology for Vostok by adjusting the age-depth curve to bring the $\mathrm{O}_{2} / \mathrm{N}_{2}$ record into closer alignment with $78^{\circ} \mathrm{S}$ summer insolation. Instead, however, we provisionally retain the $\delta^{18} \mathrm{O}_{\mathrm{atm}}$ chronology for Vostok, since it already gives an excellent match between $\mathrm{O}_{2} / \mathrm{N}_{2}$ and insolation.

Recent advances in radiometric dating allow us to test the absolute chronology defined by the orbitally tuned $\delta^{18} \mathrm{O}_{\mathrm{atm}}$ record. We make three comparisons of the $\delta^{18} \mathrm{O}_{\mathrm{atm}}$ chronology with radiometrically dated events. First, we compare dates for interglacial $\delta^{18} \mathrm{O}_{\mathrm{atm}}$ minima at Vostok with radiometric ages of maximum interglacial high sea stands. This comparison invokes the fact that $\delta^{18} \mathrm{O}$ of seawater tracks sea level (ice volume) variations, and photosynthesis transmits these variations to atmospheric $\mathrm{O}_{2}[11,52]$. We arbitrarily consider that high sea stands correspond to periods when $\delta^{18} \mathrm{O}_{\text {atm }}$ was within $0.2 \%$ of its interglacial minimum. We add $1 \mathrm{kyr}$ to the ages of these intervals. This addition corrects for the lag with which $\delta^{18} \mathrm{O}_{\mathrm{atm}}$ tracks $\delta^{18} \mathrm{O}$ of seawater, due to the $\sim 1$ kyr turnover time of $\mathrm{O}_{2}$ in air. By this criterion, high sea stands following terminations 2, 3, and 4 date to $119-127,235-240$, and 328-335 ka. These ages compare well with radiometric ages for the corresponding high sea stands: 116$128 \mathrm{ka}$ for stage 5e [3,53], 228-237 ka for stage 7e [4] (with error limits extending to $245 \mathrm{ka}$ ), and $324 \pm 3$ to $334 \pm 4 \mathrm{ka}$ for stage 9 [5]. Deriving the age of the current high sea stand in this way gives 5-9 ka. It is thus a reasonable measure of the early part of the high stand, but underestimates the duration. This underestimate is caused by precession forcing of the biogeochemical influence on $\delta^{18} \mathrm{O}_{\mathrm{atm}}$ [11], which leads to an increase in 
$\delta^{18} \mathrm{O}_{\mathrm{atm}}$ during the high sea stand, illustrating a limitation of the general approach. We also note that most of the deglacial sea level rise during termination 2 came well before $[54,55]$ the period of highest sea level that is radiometrically dated by the studies cited above. (The Vostok orbital chronology is generally in good agreement with the timescale of Landwehr and Winograd [56], based on mapping to the Devil's Hole record. However, the Vostok deglacial isotopic temperature rise at termination 2 lags the start of the Devil's Hole deglacial $\delta^{18} \mathrm{O}$ change by $\sim 10 \mathrm{kyr}$. The origin of this apparent discrepancy may lie in the fact that Vostok and Devil's Hole record different climate properties that do not always vary synchronously.)

Second, we show that the orbitally tuned $\delta^{18} \mathrm{O}_{\mathrm{atm}}$ chronology is nearly identical to the SPECMAP chronology of Martinson et al. [7]. We then compare ages of high sea stands inferred from the SPECMAP chronology with values from radiometric dating. Throughout the period of the Summit climate records $(\sim 115 \mathrm{ka})$, all rapid increases in $\mathrm{CH}_{4}$ concentrations are associated with rapid warming (increases in $\delta^{18} \mathrm{O}$ of ice) in Greenland (e.g., [9]). We thus compare Vostok and SPECMAP chronologies by matching periods of rapid $\mathrm{CH}_{4}$ increases observed in the Vostok record with periods of rapid warming in the long temperature record of ODP Site 980 [57], dated by correlation into the SPECMAP chronology. We recognize seven events in which rapid $\mathrm{CH}_{4}$ increases in Vostok can be confidently correlated with rapid warmings in ODP 980 (Fig. 3). On average, methane rises $0 \pm 2 \mathrm{kyr}$ before the ODP 980 temperature increase. There is thus no discernible difference between the SPECMAP and ice core $\delta^{18} \mathrm{O}_{\mathrm{atm}}$ chronologies, and we can test the latter by testing the former.

McManus et al. [57] derived a seawater $\delta^{18} \mathrm{O}$ curve for the last $500 \mathrm{ka}$ by subtracting the inferred temperature contribution from the benthic $\delta^{18} \mathrm{O}$ record of ODP 980 . According to this curve, the ages of interglacial high sea stands $5 \mathrm{e}, 7 \mathrm{e}$, and 9 are approximately $116-125 \mathrm{ka}, 239-245 \mathrm{ka}$, and 332-336 ka, respectively (Fig. 4). These ages for $5 \mathrm{e}$ and 9 are, like those estimated directly from $\delta^{18} \mathrm{O}_{\mathrm{atm}}$, in good agreement with radiometric ages of coral reefs. The age for $7 \mathrm{e}$ is at the old end of the radiometric timespan.

Third, we derive an orbital tuning record for the GISP2 ice core. Our purpose here is not to derive a new chronology for GISP2. Rather, it is to test orbital tuning during the past $100 \mathrm{ka}$. As for Vostok, GISP2 depths at midpoints of $\delta^{18} \mathrm{O}_{\text {atm }}$ decreases must have gas ages corresponding to ages of maximum June insolation in the northern hemisphere. When we correct these control points for gas age-ice age differences (which average $\sim 1$ kyr), we date the 305-m depth horizon of GISP2 at $11.4 \mathrm{ka}, 900-\mathrm{m}$ depth at $58.0 \mathrm{ka}$, and $2674-\mathrm{m}$ depth at $84.5 \mathrm{ka}$. These ages agree with the standard GISP2 timescale [13] to $\pm 0.7 \mathrm{kyr}$ or better.

Wang et al. [6] have recently published a superb radiometrically dated record of monsoon events in China based on the $\delta^{18} \mathrm{O}$ of $\mathrm{CaCO}_{3}$ speleothems in Hulu Cave. Their record spanned the last $\sim 75 \mathrm{ka}$. They showed that they could tie their cave record into the GISP2 ice core record. With the 'blue' correlation in their figure 1, age differences between maxima of correlative warm events differ by only $0.3 \pm 1.0 \mathrm{kyr}(1 \sigma)$. As noted above, the $\delta^{18} \mathrm{O}_{\text {atm }}$ chronology for GISP2 is essentially identical to the Meese et al. [13] chronology. This close agreement again supports an orbital tuning chronology based on $\delta^{18} \mathrm{O}_{\mathrm{atm}}$. Prior to 60 $\mathrm{ka}$, there is a mismatch in the relative amplitudes of correlative events between Hulu Cave and GISP2. Between $60-75 \mathrm{ka}$, there is also a mismatch in the relative amplitude of $\mathrm{CH}_{4}$ and temperature variations in the Summit ice cores (e.g., [9]). The implication is that climate teleconnections associated with rapid climate change during the past $60 \mathrm{ka}$ were weaker between $60-75 \mathrm{ka}$, and climate records are correlated with less confidence.

\section{Summary}

The $\mathrm{O}_{2} / \mathrm{N}_{2}$ ratio in trapped gases of the Vostok ice core varies cyclically with age between $\sim 160$ $385 \mathrm{ka}$. These variations are coherent with summertime insolation at Vostok. To explain this correlation, we assert that insolation influences snow metamorphism and grain properties in shallow 
firn. The insolation signature in these properties is retained throughout the firn, and influences $\mathrm{O}_{2} / \mathrm{N}_{2}$ fractionation during bubble closeoff. Results of spectral analysis, together with information about snow and firn metamorphism, support our inferred links. We thus conclude that the Vostok $\mathrm{O}_{2} / \mathrm{N}_{2}$ curve is a strip chart recording of local solar insolation.

The Vostok $\mathrm{O}_{2} / \mathrm{N}_{2}$ record supports the orbital tuning chronology based on $\delta^{18} \mathrm{O}_{\mathrm{atm}}$. This chronology is consistent with dates for the last interglacial high sea stand, the stage 9 high sea stand, and possibly stage 7 as well. An orbital tuning chronology for GISP2 is in excellent agreement with radiometric dates for correlative events in Hulu Cave [6]. This impressive confluence of chronologies suggests that the community is converging on a timescale for Pleistocene climate change that is accurate to about $\pm 3 \mathrm{kyr}$ back to about $400 \mathrm{ka}$.

\section{Acknowledgements}

Several scientists were generous in educating the author and discussing ideas about various relevant topics. Nicholas Shackleton stimulated this work with his provocative work on orbital tuning of the Vostok chronology. He discussed results of spectral analysis and pointed out the relevance of cross spectral analysis to understanding the influence of southern hemisphere insolation on $\mathrm{O}_{2} / \mathrm{N}_{2}$. Rebecca Robinson guided me on procedures for spectral analysis. Richard Alley patiently answered endless questions about snow and firn metamorphism and discussed related issues. Steven Warren and Susan Solomon gave guidance about various topics related to Antarctic meteorology and its effects on snow. Christina Gallup and Peter Molnar discussed topics of Pleistocene geochronology and made suggestions that were incorporated into this paper. Margaret Smith and Thomas Blunier thought about aspects of data interpretation with me. Previously unpublished $\mathrm{O}_{2} / \mathrm{N}_{2}$ data were collected by Joseph Orchardo, Bruno Malaize, and Mary-Lynn Dickson as part of our study of the $\delta^{18} \mathrm{O}_{\mathrm{atm}}$ record. Wally Broecker encouraged this study at an early stage.
Kurt Cuffey and Jeff Severinghaus wrote thoughtful reviews. Any errors are the author's sole responsibility. This work was supported by the NSF Office of Polar Programs.[BOYLE]

\section{References}

[1] J.W. Barnes, J.E. Lang, H.A. Potratz, Ratio of ionium to uranium in coral limestone, Science 124 (1956) 175-176.

[2] J.N. Rosholt, C. Emiliani, J. Geiss, F.F. Koxzy, P.J. Wangersky, Absolute dating of deep-sea cores by the Pa-231/Th-230 method, J. Geology 69 (1961) 162-185.

[3] C.H. Stirling, T.M. Esat, K. Lambeck, M.T. McCulloch, Timing and duration of the Last Interglacial: evidence for a restricted interval of widespread coral reef growth, Earth Planet. Sci. Lett. 160 (1998) 745-762.

[4] L.F. Robinson, G.M. Henderson, N.C. Slowey, U-Th dating of Marine Isotope Stage 7 in Bahamas Slope sediments, Earth Planet. Sci. Lett. 196 (2002) 175-187.

[5] C.H. Stirling, T.M. East, K. Lambeck, M.T. McCulloch, S.G. Blake, D.C. Lee, A.N. Halliday, Orbital forcing of the Marine Isotope Stage 9 interglacial, Science 291 (2001) 290-293.

[6] Y.J. Wang, H. Cheng, R.L. Edwards, Z.S. An, J.Y. Wu, C.C. Shen, J.A. Dorale, A High-resolution absolute-dated late Pleistocene monsoon record from Hulu Cave, China, Science 294 (2001) 2345-2348.

[7] D.G. Martinson, N.G. Pisias, J.D. Hays, J. Imbrie, T.C. Moore, N.J. Shackleton, Age dating and the orbital theory of the ice ages - development of a high-resolution 0 to 300000 -year chronostratigraphy, Quat. Res. 27 (1987) 1-29.

[8] J.J. Petit Jr., J. Jouzel, D. Raynaud, N.I. Barkov, J.M. Barnola, I. Basile, M. Bender, J. Chappellaz, J. Davis, M. Delaygue, M. Delmotte, V.M. Kotlyakov, M. Legrand, V.Y. Lipenkov, C. Lorius, L. Pepin, C. Ritz, E. Saltzman, M. Stievenard, Climate and atmospheric history of the past 420000 years from the Vostok ice core, Antarctica, Nature 399 (1999) 429-436.

[9] T. Blunier, E.J. Brook, Timing of millennia-scale climate change in Antarctica and Greenland during the last glacial period, Science 291 (2001) 109-112.

[10] C. Waelbroeck, J. Jouzel, L. Labeyrie, C. Lorius, M. Labracherie, M. Stievenard, N.I. Barkov, A comparison of the Vostok ice deuterium record and series from Southern Ocean core MD 88-770 over the last two glacial-interglacial cycles, Clim. Dyn. 12 (1995) 113-123.

[11] N.J. Shackleton, The 100000 -year ice-age cycle identified and found to lag temperature, carbon dioxide, and orbital eccentricity, Science 289 (2000) 1897-1902.

[12] F. Parrenin, J. Jouzel, C. Waelbroeck, C. Ritz, J-M. Barnola, Dating the Vostok ice core by an inverse method, J. Geophys. Res. 106 (2001) 31837-31851.

[13] D.A. Meese, A.J. Gow, R.B. Alley, G.A. Zielinski, P.M. Grootes, M. Ram, K.C. Taylor, P.A. Mayewski, J.F. Bol- 
zan, The Greenland Ice Sheet Project 2 depth-age scale: methods and results, J. Geophys. Res. Oceans 102 (1997) 26411-26423.

[14] R.G. Fairbanks, A 17000-year glacio-eustatic sea-level record - influence of glacial melting rates on the Younger Dry event and deep-ocean circulation, Nature 342 (1989) 637-642.

[15] T. Sowers, M. Bender, Climate records covering the last deglaciation, Science 269 (1995) 210-214.

[16] D. Raymaud, R. Delmas, Composition des gaz contenus dans la glace polaire, in: Isotopes and Impurities in Snow and Ice Symposium (Proceedings of the Grenoble Symposium, August-September 1975, IAHS Publ. No. 118) 1977, pp. $377-381$.

[17] T.A. Sowers, The Elemental and Isotopic Composition of Occluded $\mathrm{O}_{2}$ and N2 in Polar Ice, M.Sc. Thesis, University of Rhode Island, RI, 1988, ix+58 pp.

[18] H. Craig, Y. Horibe, T. Sowers, Gravitational separation of gases and isotopes in polar ice caps, Science 242 (1988) 1675-1678.

[19] T. Sowers, M. Bender, D. Raynaud, Elemental and isotopic composition of occluded $\mathrm{O}_{2}$ and $\mathrm{N}_{2}$ in Polar Ice, J. Geophys. Res. Atmospheres 94 (1989) 5137-5150.

[20] M. Battle, M. Bender, T. Sowers, P.P. Tans, J.H. Butler, J.T. Ellis, T. Conway, N. Zhang, P. Lang, A.D. Clarke, Nature 383 (1996) 231-235.

[21] M. Bender, T. Sowers, V. Lipenkov, On the Concentrations of $\mathrm{O}-2, \mathrm{~N}-2$, and $\mathrm{Ar}$ in trapped gases from ice cores, J. Geophys. Res. Atmospheres 100 (1995) 1865118660 .

[22] M.E. Smith, The Pleistocene $\mathrm{O}_{2}$ Record in Two Ice Cores, Senior thesis, Princeton University, Princeton, NJ, 1998, $30 \mathrm{pp}$.

[23] P. Martinerie, D. Raynaud, D.M. Etheridge, J.M. Barnola, D. Mazaudier, Physical and climatic parameters which influence the air content in polar ice, Earth Planet. Sci. Lett. 112 (1992) 1-13.

[24] V.Ya. Lipenkov, A.N. Salamatin, P. Duval, Bubbly ice densification in ice sheets. II. Applications, J. Glaciol. 43 (1997) 397-407.

[25] M.L. Bender, T. Sowers, J.M. Barnola, J. Chappellaz, Changes in the $\mathrm{O}_{2} / \mathrm{N}_{2}$ ratio of the atmosphere during recent decades reflected in the composition of air in the firn at Vostok Station, Antarctica, Geophys. Res. Lett. 21 (1994) 189-192.

[26] T. Uchida, T. Hondoh, S. Mae, V.Ya. Lipenkov, P. Duval, Air-hydrate crystals in deep ice-core samples from Vostok Station, Antarctica, J. Glaciol. 40 (1994) 78-86.

[27] T. Ikeda, H. Fukazawa, S. Mae, L. Pepin, P. duval, B. Champagnoon, V.Ya. Lipenkov, T. Hondoh, Extreme fractionation of gases caused $\mathrm{y}$ formation of clathrate hydrates in Vostok Antarctic ice, Geophys. Res. Lett. 26 (1999) 91-94.

[28] J.M. Palais, I.M. Whillans, C. Bull, Snow stratigraphic studies at Dome C, east Antarctica: an investigation of depositional and diagenetic processes, Ann. Glaciol. 3 (1982) 239-242.
[29] R.B. Alley, Concerning the deposition and diagenesis of strata in polar firn, J. Glaciol. 34 (1988) 283-290.

[30] K. Steffen, W. Abdalati, I. Sherjal, Faceted crystal formation in the northeast Greenland low-accumulation region, J. Glaciol. 45 (1999) 63-68.

[31] B. Malaize, D. Paillard, J. Jouzel, D. Raynaud, The Dole effect over the last two glacial-interglacial cycles, J. Geophys. Res. Atmospheres 104 (1999) 14199-14208.

[32] M. Bender, T. Sowers, L. Labeyrie, The Dole effect and its variation during the last 130000 years as measured in the Vostok ice core, Glob. Biogeochem. Cycles 8 (1994) 363-376.

[33] R.E. Brandt, S.G. Warren, Temperature measurements and heat transfer in near-surface snow at the South Pole, J. Glaciol. 43 (1997) 339-351.

[34] R.E. Brandt, S.G. Warren, Solar-heating rates and temperature profiles in Antarctic snow and ice, J. Glaciol. 39 (1993) 99-110.

[35] J.H.G. Glendinning, E.M. Morris, Incorporation of spectral and directional radiative transfer in a snow model, Hydrol. Proc. 13 (1999) 1761-1772.

[36] R.B. Alley, E.S. Saltzman, K.J. Cuffey, J.J. Fitzpatrick, Summertime formation of depth hoar in central Greenland, Geophys. Res. Lett. 17 (1990) 2393-2396.

[37] Dahe Qin, J.-W. Ren, A study on snow profiles and surface characteristics along $6000 \mathrm{~km}$ Trans-Antarctic Route (1), Sci. China Ser. B 35 (1992) 366-374.

[38] T.C. Grenfell, S.G. Warren, P.C. Mullen, Reflection of solar radiation by the Antarctic snow surface at ultraviolet, visible, and near-infrared wavelengths, J. Geophys. Res. 99 (1994) 18669-18684.

[39] T. Aoki, T. Aoki, M. Fukabori, A. Uchiyama, Numerical simulation of the atmospheric effects on snow albedo with a multiple scattering radiative transfer model for the atmosphere-snow system, J. Meterol. Soc. Jpn. 77 (1999) 595-614.

[40] T. Nakamura, O. Abe, T. Hasegawa, R. Tamura, T. Ohta, Spectral reflectance of snow with a known grainsize distribution in successive metamorphism, Cold Regions Sci. Technol. 32 (2001) 13-26.

[41] J.C. King, J. Turner, Antarctic Meteorology and Climatology, Cambridge University Press, Cambridge, 1997, xi+409 pp.

[42] R.B. Alley, Texture of polar firn for remote sensing, Ann. Glaciol. 9 (1987) 1-4.

[43] L. Jun, N.W. Young, C.W. Wookey, Stratigraphy density and crystal structure of firn-ice at DE08: a very high accumulation site on Law Dome, Antarctica, Antarct. Res. 2 (1991) 1-14.

[44] M. Nakawo, Ice fabric studies on a 75 m-long core drilled at Mizuho Camp, East Antarctica, Antarct. Rec. 50 (1974) 29-34.

[45] L. Jun, T.H. Jacka, Crystal-growth rates in firn and shallow ice at high-accumulation sites, Ann. Glaciol. 29 (1999) 169-175.

[46] P. Duval, Grain growth and mechanical behaviour of polar ice, Ann. Glaciol. 6 (1985) 79-82. 
[47] A.J. Gow, On the rates of growth of grains and crystals in south polar firn, J. Glaciol. 8 (1969) 241-252.

[48] R.B. Alley, Firn densification by grain-boundary sliding: a first model, J. Phys. Colloq. C1 48 (1987) 249-256.

[49] L. Arnaud, Modelisation de la transformation de la neige en glace a la surface des calottes polaires: etude du transport des gaz dans ces mileiux poreux, Ph.D. Thesis, University of Grenoble, 1997, $297 \mathrm{pp}$.

[50] R.B. Alley, J.H. Perepezko, C.R. Bentley, Grain growth in polar ice. II. Application, J. Glaciol. 32 (1986) 112.

[51] M.L. Bender, B. Malaize, J. Orchardo, T. Sowers, J. Jouzel, High precision correlations of Greenland and Antarctica over the last $100 \mathrm{kyr}$, in: Mechanisms of Global Climate Change at Millenial Timescales Geophysical Monograph 112, P. Clark, R. Webb, L. Keigwin (Eds.), American Geophysical Union, Washington, 1999, pp. 149-164.

[52] T. Sowers, M. Bender, L. Labeyrie, D. Martinson, J. Jouzel, D. Raynaud, J. Pichon, Y. Korotkevich, A $135000-$ year Vostok-SPECMAP common temporal framework, Paleoceanogr. 8 (1993) 737-766.

[53] C.H. Stirling, T.M. Esat, M.T. McCulloch, K. Lambeck, High-precision U-series dating of corals from Western Australia and implications for the timing and duration of the Last Interglacial, Earth Planet. Sci. Lett. 135 (1995) 115-130.

[54] C.D. Gallup, H. Cheng, F.W. Taylor, R.L. Edwards, Direct determination of the timing of sea level change during Termination II, Science 295 (2002) 310-313.

[55] G.M. Henderson, N.C. Slowey, Evidence from U-Th dating against northern hemisphere forcing of the penultimate deglaciation, Nature 404 (2000) 61-66.

[56] J.M. Landwehr, I.J. Winograd, Dating the Vostok ice core record by importing the Devil's Hole chronology, J. Geophys. Res. Atmospheres 106 (2001) 31853-31861.

[57] J.F. McManus, D.W. Oppo, J.L. Cullen, A 0.5-millionyear record of millennial-scale climate variability in the North Atlantic, Science 283 (1999) 971-975. 